\title{
PENGARUH MODEL PEMBELAJARAN CONCEPT SENTENCE BERBANTUAN FLASH CARD TERHADAP KOMPETENSI PENGETAHUAN IPA
}

\author{
Ni Pt Pitri Febriani ${ }^{1}$, I Gst. Agung Oka Negara ${ }^{2}$, I Km. Ngurah Wiyasa ${ }^{3}$ \\ 1,2,3 Jurusan Pendidikan Guru Sekolah Dasar, FIP \\ Universitas Pendidikan Ganesha \\ Singaraja, Indonesia \\ email : pitri.febriani@gmail.com ${ }^{1}$, igustiagungoka.negara@undiksha.ac.id ${ }^{2}$, ngrh.wiyasa@undiksha.ac.id
}

\begin{abstract}
Abstrak
Penelitian ini bertujuan untuk mengetahui pengaruh yang signifikan kompetensi pengetahuan IPA siswa yang dibelajarkan dengan model pembelajaran Concept Sentence berbantuan Flash Card dan siswa yang dibelajarkan dengan pembelajaran konvensional pada siswa kelas V SD Negeri Gugus Budi Utomo Denpasar Timur tahun ajaran 2017/2018. Desain penelitian ini menggunakan rancangan nonequivalent control group design. Populasi penelitian ini adalah seluruh siswa kelas V SD Negeri Gugus Budi Utomo Denpasar Timur yang berjumlah 337 orang. Penentuan sampel dilakukan dengan teknik random sampling. Sampel dalam penelitian ini adalah siswa kelas V SD N 8 Kesiman dengan jumlah 40 siswa sebagai kelompok eksperimen dan siswa kelas VB SD N 1 Kesiman dengan jumlah 36 siswa sebagai kelompok kontrol. Pengumpulan data dilakukan dengan menggunakan metode tes dalam bentuk tes objektif pilihan ganda biasa. Data dianalisis menggunakan uji-t. Berdasarkan hasil analisis data diperoleh $t_{\text {hitung }}=4,132$ dan $t_{\text {tabe }} l$ (pada taraf signifikansi $5 \%$ dengan $\mathrm{dk}=74$ ) nilai ttabel $=2,000$ sehingga thitung $=4,132>$ ttabel $=2,000$. Berdasarkan kriteria pengujian,terdapat perbedan yang signifikan Model Pembelajaran Concept Sentence berbantuan Flash Card terhadap kompetensi pengetahuain IPA siswa kelas V SD Negeri Gugus Budi Utomo Denpasar Timur, jadi dapat disimpulkan bahwa model pembelajaran Concept Sentenceberbantuan Flash Card memberikan pengaruh terhadap kompetensi Pengetahuan IPA.
\end{abstract}

Kata kunci: cocept sentence, flash card kompetensi pengetahuan IPA

\begin{abstract}
The purpose of this research was to know the significant differences of the competence of science between the students group which is learned through Concept Sentence assisted by Flash Card and the students which is learned through conventional learning model of fifth grade SD Gugus Budi Utomo, Denpasar Timur academic year 2017/2018. The design of this research is nonequivalent control group design. The research population of all students fifth grade in SD Negeri Gugus Budi Utomo Denpasar Timur totalling 337 students. It uses random sampling technique. The sample of this research is the fifth grader of SD Negeri 8 Kesiman with totalling 40 students as experimental group and fifth B grader of SD Negeri 1 Kesiman with totalling 36 students as the control group. The data collection was done by test method and the instrument was in the form of ordinary double choice objective test. Data analyzed by using t-test. Based on the data analysis results obtained tct $=4.132$ and ttable (at $5 \%$ significance level with $\mathrm{dk}=74$ ) ttable $=2,000$ so thitung $=4.132>$ ttable $=2,000$. Based on the criteria, there is a significant difference Concept Sentence Learning Model with Flash Card to the knowledge competence of science of fifth grade students at SD Negeri Gugus Budi Utomo East Denpasar, so it can be concluded that the learning model of Concept Sentence with Flash Card is giving influence to Knowledge Science competence.
\end{abstract}

Keywords: Concept Sentence, Flash Card, knowledge competence of science. 


\section{Pendahuluan}

Kualitas sumber daya manusia (SDM) memiliki peranan yang sangat penting bagi kelangsungan suatu bangsa. Salah satu faktor yang mendukung terbentuknya kualitas SDM yang baik adalah pendidikan. "Makna pendidikan sebagai usaha manusia untuk menumbuhkan dan mengembangkan potensi-potensi pembawaan, baik jasmani maupun rohani sesuai dengan nilai-nilai yang ada dalam masyarakat dan kebudayaan" (Anwar, 2015:19). Dapat disimpulkan bahwa pendidikan adalah suatu usaha untuk mengembangkan segala potensi yang ada dalam diri peserta didik sesuai dengan nilai-nilai kebudayaan dan akhlak mulia. Sekolah dasar sebagai jenjang pendidikan dasar yang pertama memegang peranan yang sangat penting. Mengingat bahwa siswa belajar secara formal pertama kalinya pada jenjang sekolah dasar.

Kurikulum merupakan salah satu faktor yang dapat dijadikan acuan dalam pembelajaran.Kurikulum adalah tonggak utama daripada pendidikan itu sendiri. Kurikulum adalah salah satu faktor yang dapat dijadikan acuan dalam pembelajaran. Kurikulum terus mengalami perubahan karena "berhasil dan tidaknya sebuah pendidikan sangat dipengaruhi oleh kurikulum yang ada" (Fadlillah, 2014:17). Sependapat dengan hal tersebut (Mulyasa, 2009:4) menyatakan, "kurikulum merupakan komponen pendidikan yang dijadikan acuan oleh setiap satuan pendidikan, baik oleh pengelola maupun penyelenggara; khususnya oleh guru dan kepala sekolah".

Kurikulum yang berlaku sekarang di sekolah dasar adalah Kurikulum 2013, yang mulai diterapkan pada tahun pelajaran 2013/2014. Kurikulum 2013 adalah pengembangan dari kurikulum yang telah ada sebelumnya, baik Kurikulum Berbasis Kompetensi (KBK), dan Kurikulum Tingkat Satuan Pendidikan (KTSP). Kurikulum 2013 menekankan adanya keseimbangan antara aspek kompetensi sikap, keterampilan dan pengetahuan.

Tujuan dari kurikulum 2013 adalah untuk meningkatkan rasa ingin tahu siswa dan mendorong siswa menjadi lebih aktif. Pada kurikulum ini siswa tidak lagi menjadi objek, justru siswa menjadi subjek dengan ikut mengembangkan tema yang ada.

Pembelajaran pada kurikulum 2013 berbeda dengan kurikulum-kurikulum sebelumnya. Sebab pembelajaran pada kurikulum 2013 ini menggunakan pendekatan saintifik dan tematik intregatif. Tujuan dari kurikulum 2013 adalah untuk meningkatkan rasa ingin tahu siswa dan mendorong siswa menjadi lebih aktif. Pada kurikulum ini siswa tidak lagi menjadi objek, justru siswa menjadi subjek dengan ikut mengembangkan tema yang ada.

Pada kenyataanya, seringkali siswa yang aktif dalam setiap pertemuan adalah orang yang sama, yang menunjukkan bahwa siswa lainnya kurang aktif dalam setiap pembelajaran. Sehingga materi yang dibelajarkan perlu dikemas agar menjadi lebih menarik.

Oleh karena itu diperlukan guru yang memiliki kemampuan dan pengetahuan untuk mengemas suatu proses pembelajaran menjadi interaktif, inspiratif, menyenangkan, menantang, dan memotivasi peserta didik untuk berpartisipasi aktif, serta memberikan ruang yang cukup bagi kreativitas sesuai dengan bakat, minat dan perkembangan fisik peserta didik.

Keberhasilan dalam menyampaikan materi saat proses pembelajaran berlangsung, sangat tergantung pada kelancaran interkasi komunikasi antara guru dengan siswa, dan antara siswa dengan siswa lainnya. Guru yang profesional akan dapat menumbuhkan semangat dan motivasi siswa dalam belajar, sehingga pembelajaran dapat berjalan secara optimal dan sesuai dengan yang diharapkan.

Masalah yang dihadapi pada dunia pendidikan saat ini adalah kurang kuatnya proses pembelajaran yang diterapkan guru di sekolah. Pelaksanaan proses pembelajaran yang berlangsung di kelas masih diarahkan pada kemampuan siswa untuk mengahafal informasi tanpa dituntut memahami informasi yang diperoleh dan menghubungkannya dengan situasi dalam kehidupan sehari-hari. Hal ini menyebabkan siswa hanya tidak mengerti secara menyeluruh, karena masih mengutamakan belajara secara mengingat atau hafalan. Kondisi ini pun terjadi pada Kurikulum 2013, salah satunya pada kompetensi pengetahuan IPA.

Berdasarkan Kurikulum 2013 siswa menggunakan pembelajaran tematik terpadu salah satunya yang diobservasi pada kompetensi pengetahuan IImu Pengetahuan Alam (IPA). "IPA merupakan rumpun ilmu, memiliki karakteristik khusus yaitu mempelajari fenomena alam yang 
faktual (factual), baik berupa kenyataan (reality) atau kejadian (events) dan hubungan sebabakibatnya." (Wisudawati dan Sulistyowati, 2015:22). "IPA merupakan salah satu mata pelajaran pokok dalam kurikulum pendidikan di Indonesia, termasuk pada jenjang sekolah dasar" (Susanto, 2015:165). Ilmu pengetahuan alam merupakan terjemahan kata-kata dalam bahasa Inggris yaitu natural science, artinya ilmu pengetahuan alam (IPA). Berhubungan dengan alam atau bersangkut paut dengan alam, science artinya ilmu pengetahuan. Jadi ilmu pengetahuan alam (IPA) atau science dapat disebut sebagai ilmu tentang alam. IImu yang mempelajari peristiwa-peristiwa yang terjadi di alam ini. "IPA membahasa tentang gejala-gejala alam yang disusun secara sistemastis yang didasarkan pada hasil percobaan dan pengamatan yang dilakukan oleh manusia, gejala-gejala alam yang terdapat di lingkungan sekitar dapat dijadikan sebagai pengamatan dan percobaan dalam pemebelajaran IPA" (Samatowa, 2016:3)IPA sangat erat kaitannya dengan kehidupan manusia, mulai dari seorang manusia dilahirkan, kelangsungan kehidupan, dan segala sesuatu tentang kehidupan berhubungan dengan IPA. Pembelajaran IPA di sekolah dasar merupakan tonggak awal IPA pada jenjang pendidikan selanjutnya.

Pada kenyataan implementasi kurikulum 2013 dalam pembelajaran masih jauh dari apa yang diharapkan, dari observasi yang dilakukan di kelas V SD Negeri Gugus Budi Utomo Denpasar Timur pada tanggal 9 dan 10 Januari 2018 ditemui beberapa masalah dalam proses pembelajaran. Dalam proses pembelajaran IPA ditemui kendala yang di hadapi sehingga mempengaruhi penguasaan kompetensi pengetahuan IPA siswa yang belum optimal.

Salah satu kendalanya adalah terkadang siswa kurang bersemangat dan kehilangan fokus. Hal tersebut sangat berpengaruh terhadap penguasaan kompetensi pengetahuan siswa. Hal ini terlihat dari nilai rata-rata hasil belajar siswa khususnya dalam bidang IPA masih kurang dari apa yang diharapkan, mengingat pentingnya pembelajaran tentang IPA. "IPA merupakan salah satu mata pelajaran pokok dalam kurikulum pendidikan di Indonesia, termasuk pada jenjang sekolah dasar" (Susanto, 2015:165). Ilmu pengetahuan alam merupakan terjemahan kata-kata dalam bahasa Inggris yaitu natural science, artinya ilmu pengetahuan alam (IPA). Berhubungan dengan alam atau bersangkut paut dengan alam, science artinya ilmu pengetahuan. Jadi ilmu pengetahuan alam (IPA) atau science dapat disebut sebagai ilmu tentang alam. Ilmu yang mempelajari peristiwa-peristiwa yang terjadi di alam ini. "IPA membahasa tentang gejala-gejala alam yang disusun secara sistemastis yang didasarkan pada hasil percobaan dan pengamatan yang dilakukan oleh manusia, gejala-gejala alam yang terdapat di lingkungan sekitar dapat dijadikan sebagai pengamatan dan percobaan dalam pemebelajaran IPA" (Samatowa, 2016:3)

Hal ini dikarenakan saat proses pembelajaran berlangsung siswa terlihat masih bergantung pada guru dan belum membiasakan diri dalam mencari, membangun, dan membuka wawasannya sendiri. Salah satu penyebabnya adalah model pembelajaran yang digunakan guru kurang bervariasi. Selain itu media pembelajaran yang digunakan juga kurang menarik perhatian siswa dalam pembelajaran yang berlangsung.

Pelaksanaan pembelajaran di kelas perlu didesain secara kreatif dan inovatif dengan memperhatikan karakteristik perkembangan siswa kelas V SD. Dari uraian masalah tersebut dipandang perlu adanya inovasi dalam pembelajaran yakni pembelajaran yang mengutamakan penguasaan kompetensi, pembentukan karakter, memberikan pengalaman belajar, dan relevan dengan kehidupan nyata. Khususnya pada kompetensi pengetahuan IPA. Salah satu model pembelajaran yang dapat menuntaskan masalah pada proses pembelajaran adalah Model Pembelajaran Concept Sentence berbatuan Flash Card.

"Model pembelajaran Concept Sentence adalah model pembelajaran yang dilakukan dengan memberikan kartu-kartu yang berisi beberapa kata kunci kepada siswa. Kemudian, kata kunci tersebut disusun menjadi beberapa kalimat dan dikembagkan menjadi paragrafparagraf." (Shoimin, 2014:37). Kelebihan model pembelajaran Concept Sentence ini yakni, 1) meningkatkan semangat belajar siswa, 2) membantu terciptanya suasana belajar yang kondusif, 3) memunculkan kegemebiraan dalam belajar, 4) mendorong dan mengembangkan proses berpikir kreatif, 5) mendorong siswa untuk memandang sesuatu dalam pandangan yang berbeda, 6) memunculkan kesadaran untuk berubah menjadi lebih baik, 7) memperkuat 
kesadaran diri, 8) lebih memahami kata kunci dari materi pokok pelajaran, dan 9) siswa yang lebih pandai mengajarkan siswa yang kurang pandai. (Huda, 2014). Model pembelajaran ini diawali dengan menyampaikan kompetensi, sajian materi, membentuk kelompok secara heterogen, guru menyiapkan kata kunci sesuai materi bahan ajar, dan tiap kelompok membuat kalimat berdasarkan kata kunci. Prosedur selanjutnya dalam pembelajaran ini adalah mempresentasikan hasil belajar secara bergantian di depan kelas.Model Pembelajaran Concept Sentence ini cocok dengan media Flash Card atau Card Education."Pengertian media dalam proses belajar mengajar cenderung diartikan sebagai alat-alat grafis, photografis, atau elektronis untuk menangkap, memproses dan menyusun kembali informasi visual atau verbal." (Arsyad, 2009:3). Jadi, media pembelajaran adalah alat yang digunakan sebagai pembawa informasi atau pesan pembelajaran yang sesuai dengan kebutuhan siswa.

"flash card (bahasa Inggris) adalah kartu pelajaran. Digunakan dalam kegiatan pembelajaran melalui aktivitas permainan" (Said dan Budimanjaya, 2015:211). Selain itu Mulyorini (2014) menyatakan flash card adalah kartu kecil yang berisi gambatr, teks, atau tanda symbol yang mengingatkan dan menentukan siswa kepada sesuatu yang berhubungan dengan gambar itu.

Penelitian dengan menggunakan model model pembelajaran Concept Sentence dan media Flash Card, didukung oleh penelitian yang relevan, yakni Penelitian yang dilakukan oleh Aristyono (2017) Perbedaan hasil belajar IPA siswa SD ditinjau dari metode Mind Mapping dan model Concept Sentence, bahwa model Concept Sentence berpengaruh terhadap hasil belajar IPA. Penelitian yang dilakukan oleh Mulyorini (2014) menyatakan bahwa penggunaan media Flash card dalam Model Pembelajaran Langsung untuk meningkatkan hasil belajar siswa pada mata pelajaran PKn Kelas V SDN Ngagel Rejo I/ 396 Surabaya. Penelitian yang dilakukan oleh Prayogo (2015) yang menyatakan bahwa penggunaan media Kartu Bergambar berpengaruh terhadap hasil belajar IPA Siswa kelas V SD Negeri 3 Labuhan Ratu Kota Bandar Lampung tahun ajaran 2014/2015. Pembelajaran melalui flash card ini tergolong dalam pembelajaran yang bersifat permainan. Hal ini sesuai dengan karakteristik siswa SD sehingga cocok digunakan dalam pembelajaran.

Adanya model pembelajaran tersebut yang berbantuan Flash Card dapat menumbuhkan rasa semangat, rasa ingin tahu, serta dapat merangsang siswa untuk lebih bisa berfikir kreatif dan bekerja keras dalam memecahkan suatu masalah yang diberikan guru.

Dari uraian tersebut, maka dilakukan penelitian dengan judul "Pengaruh Model Pembelajaran Concept Sentence Berbantuan Flash Card Terhadap Kompetensi Pengetahuan IPA Pada Siswa Kelas V SD Negeri Gugus Budi Utomo Denpasar Timur Tahun Ajaran $2017 / 2018$

\section{Metode}

Penelitian ini akan dilaksanakan di Kelas V pada semester genap tahun ajaran 2017/2018 di SD Negeri Gugus Budi Utomo Denpasar Timur. Jenis penelitian yang dilakukan dalam penelitian ini adalah penelitian kuantitatif dengan desain eksperimental yaitu quasi eksperiment (Eksperimen Semu) dengan bentuk Nonequivalent Control Group Design.

Populasi dalam penelitian ini adalah siswa kelas V di SD Negeri yang terdapat pada Gugus Budi Utomo Denpasar Timur Tahun Ajaran 2017/2018 yang berjumlah 9 kelas dengan 337 siswa.

Dari populasi yang telah ditentukan maka selanjutnya diambil perwakilan dari populasi tersebut yang dianggap mewakili seluruh populasi. Perwakilan dari populasi yang mewakili seluruh populasi disebut sampel.Jadi dapat disimpulkan dari pengertian yang sudah dipaparkan, sampel adalah sejumlah kelompok kecil yang mewakili populasi untuk dijadikan sebagai objek penelitian.

Teknik pengambilan sampel pada penelitian ini adalah Random Sampling. Random sampling dipilih dikarenakan dalam penelitian ini tidak dilakukan pengecakan individu, melainkan hanya melakukan pengacakan kelas.sehingga setiap kelas mendapatkan peluang yang sama untuk menjadi sampel penelitian. Pemilihan sampel penelitian ini tidak dilakukannya 
pengacakan individu melainkan hanya pengacakan kelas. Hal ini disebabkan karena tidak bisa mengubah kelas yang telah terbentuk sebelumnya. Kelas dipilih sebagaimana telah terbentuk tanpa campur tangan peneliti dan tidak dilakukannya pengacakan individu, kemungkinan pengaruh-pengaruh dari keadaan siswa mengetahui dirinya dilibatkan dalam eksperimen dapat dikurangi sehingga penelitian ini benar-benar menggambarkan pengaruh perlakuan yang diberikan.

Cara yang digunakan adalah dengan cara pengundian. Cara pengundian dilakukan dengan menulis semua nama kelas $\mathrm{V}$ di seluruh SD populasi pada masing-masing kertas yang jumlahnya 9 kelas, kemudian kertas digulung. Masukkan gulungan kertas ke dalam kotak dan diundi dengan cara dikocok, ambil satu gulungan kertas, lalu ambil satu gulungan kertas lain tanpa memasukkan gulungan kertas yang pertama. Nama SD pada gulungan kertas tersebut merupakan sampel penelitian. Lalu kesetaraan sampel dilakukan dengan rumus uji-t yakni dengan polled varian. Setelah kedua kelompok dinyatakan setara, peneliti melakukan pengundian lagi dari SD tersebut untuk memilih kelas yang digunakan sebagai kelompok kontrol dan kelompok eksperimen.

Berdasarkan hasil analisis uji-t didapat thitung $=0,448$ dan ttabel pada taraf signifikan $5 \%$ dengan derajat kebebasan $\mathrm{dk}=(\mathrm{n} 1+\mathrm{n} 2-2)=2,000$. Sehingga thitung ttabel $(0,448<2,000)$.Berdasarkan uji-t kesetaraan yang telah dilakukan diperoleh bahwa kedua kelas tersebut setara. Sebelum dilakukan uji-t data hasil pretest diuji prasyarat drngan uji Normalitas.

Berdasarkan perhitungan hasil uji normalitas sebaran data nilai pre-test kelompok eksperimen $\mathrm{X}^{2}$ hitung $=4,79$ dan $\mathrm{X}^{2}$ tabel $=11,07$, karena $\mathrm{X} 2$ hitung $<\mathrm{X}^{2}$ tabel maka data berdistribusi normal.Berdasarkan perhitungan hasil uji normalitas nilai pre-test kelompok kontrol $\mathrm{X}_{\text {hitung }}^{2}=1,18$ dan $\mathrm{X}_{\text {tabel }}^{2}=11,07$, karena $\mathrm{X}_{\text {hitung }}<\mathrm{X}_{\text {tabel }}^{2}$ maka data berdistribusi normal.

Setelah uji normalitas dilakukan, selanjutnya dilakukan uji homogenitas. Uji homogenitas varian dilakukan dengan menggunakan uji $F$. Kriteria pengujian jika $F_{\text {hitung }}<F_{\text {tabel, }}$ maka sampel homogen. Pengujian dilakukan pada taraf signifikansi $F_{\text {tabel }}$ (pada taraf signifikansi $5 \% \mathrm{db}(35,39))$ Berdasarkan uji homogenitas varians $F_{\text {hitung }}=1,03$ dan $F_{\text {tabel }}=1,76$, karena Fhitung < Ftabel maka dapat disimpulkan data homogen.

Pada uji normalitas dan uji homogenitas hasil data pretest diketahui bahwa data yang diperoleh dari kedua sampel berdistribusi normal dan memiliki varian yang homogeny, sehingga uji prasarat dapat terpenuhi. Selanjutnya data hasil pretest diuji kesetaraan menggunakan uji-t.

Karena data nilai pre-test kelompok eksperimen dan kelompok kontrol berdistribusi normal dan homogen dilanjutkan dengan melakukan uji kesetaraan dengan uji-t. Berdasarkan hasil analisis didapat $t_{\text {hitung }}=0,44$ dan $t_{\text {tabel }}$ pada taraf signifikan $5 \%$ ( $\left.d k=74\right)$ dengan derajat kebebasan $d k=\left(n_{1}+n_{2}-2\right)=2,000$. Sehingga $t_{\text {hitung }} \leq t_{\text {tabel }}(0,448 \leq 2,000)$. Hal tersebut menunjukkan bahwa kedua sampel setara. Kemudian peneliti melakukan pengundian pada kedua sampel untuk menentukan kelas yang akan menjadi kelas eksperimen dan kelas kontrol. Setelah diundi untuk mencari kelas eksperimen dan kelas kontrol, undian yang muncul adalah SDN 8 Kesiman kelas $V$ dengan jumlah siswa 40 sebagai kelompok eksperimen dan SDN 1 Kesiman kelas VB dengan jumlah siswa 36 sebagai kelompok kontrol.

Metode yang digunakan untuk pengumpulan data yaitu menggunakan tes. Instrumen yang digunakan, yaitu tes objektif. Bentuk tes objektif tersebut adalah pilihan ganda biasa yang meliputi empat pilihan jawaban ( $a, b, c$, dan d).Kompetensi pengetahuan yang diukur dalam penelitian ini adalah kompetensi pengetahuan IPApada aspek kognitif. Aspek kognitif menurut Kosasih (2015) ada , 6 aspek yaitu : a) Mengingat $-\mathrm{C} 1=$ Cognitif 1, b) Memahami - C2 = Cognitif 2, c) Menerapkan, Mengaplikasi $-\mathrm{C} 3=$ Cognitif 3, d) Menganalisis $-\mathrm{C} 4=$ Cognitif 4 e) Mengevaluasi $-\mathrm{C} 5=$ Cognitif f) Mencipta $-\mathrm{C} 6=$ Cognitif 6

Aspek kognitif kompetensi pengetahuan IPA yang akan diukur dalam penelitian ini hanya $\mathrm{C} 1, \mathrm{C} 2, \mathrm{C} 3$, dan $\mathrm{C} 4$. Kompetensi yang diukur dalam penelitian ini adalah kompetensi pengetahuan IPA pada aspek kognitif pada siswa kelas V SD Negeri Gugus Budi Utomo Denpasar Timur Tahun Ajaran 2017/2018. 
Kompetensi pengetahuan yang diukur terdiri dari mengingat (C1), memahami (C2), menerapkan (C3), dan menganalisis (C4) dengan dimensi pengetahuan khususnya diSD adalah pengetahuan faktual dan konseptual. Setelah diberikan perlakukan sebanyak masingmasing 6 kali, baik pada kelas eksperimen maupun kelas control, dilakukanlah pengujian instrument untuk soal Posttes. Dimana uji coba instrument ini dilakukan di kelas yang lebih tinggi yaitu kelas 6 SDN 1 Kesiman dan Kelas ^ SDN 8 Kesiman dengan total siswa untuk uji coba intrumen berjumlah 61 siswa. Pengujian instrumen penelitian, yaitu uji validitas, uji reliabilitas, uji daya beda, dan tingkat kesukaran.

Metode analisis statistik yang digunakan dalam penelitian ini mengenai statistik deskriptif dan statistik inferensial. "Tujuan analisis data adalah untuk mengadakan generalisasi terhadap sifat-sifat, kondisi-kondisi, atau hubungn-hubungan yang bersifat khusus, sehingga diperoleh kondisi-kondisi, sifat-sifat, hubungan-hubungan yang bersifat umum" (Agung, 2014:109).Analisis data deskriptif adalah menganalisis data dengan mendeskripsikan atau menggambarkan data-data yang sudah dikumpulkan. Pada penelitian ini, statistik deskriptif digunakan untuk menjawab rumusan masalah 1 dan 2 yakni untuk mengetahui penguasaan kompetensi pengetahuan IPA setelah dibelajarkan melalui model pembelajaran Concept Sentence berbantuan Flash Card dan penguasaan kompetensi pengetahuan IPA setelah dibelajarkan melalui pembelajaran konvensional.Penyajian data yang digunakandalam statistik deskriptif ini adalah melalui Mean (menghitung rata-rata) dan standar deviasi dan varians.

Statistik inferensial ini digunakan untuk menjawab rumusan masalah 3 yakni untuk mengetahui pengaruh yang signifikan model pembelajaran Concept Sentence berbantuan Flash Card terhadap kompetensi pengetahuan IPA kelas V SD Negeri Gugus Budi Utomo Denpasar Timur tahun ajaran 2017/2018.

Adapun hipotesis penelitian yang diuji, yaitu: Tidak terdapat pengaruh yang signifikan Model PembelajaranConcept Sentence berbantuan Flash Card terhadap kompetensi pengetahuan IPA siswa kelas V SD Negeri Gugus Budi Utomo Denpasar Timur tahun ajaran $2017 / 2018$.

\section{Hasil Dan Pembahasan}

Hasil penelitian ini memaparkan mengenai nilai rata-rata (mean), standar deviasi, dan varians dari data kompetensi pengetahuan IPA siswa kelas V tema 8 (lingkungan sahabat kita). Data yang diperoleh dalam penelitian ini dikelompokkan menjadi dua, yaitu, data kompetensi pengetahuan IPA kelompok eksperimen dan data kompetensi pengetahuan IPA kelompok kontrolyang diperoleh dari tes pilihan ganda biasa dengan 4 pilihan jawaban. Tes kompetensi pengetahuan IPA yang dilakukan setelah 6 kali perlakuan. Banyak siswa pada kelompok eksperimen 40 siswa dan kelompok kontrol 36 siswa.

Hasil penelitian ini menunjukkan bahwa kompetensi pengetahuan IPA yang dicapai siswa yang belajar menggunakan model pembelajaran Concept Sentence Berbantuan Flash Card berbeda dengan siswa yang belajar dengan pembelajaran konvensional.

Nilai rata-rata kompetensi pengetahuan IPA siswa untuk kelas eksperimen yang dibelajarkan dengan Model Pembelajaran Concept Sentence adalah 81,75 dengan varians sebesar 105,09 dan standar deviasi 10,25. Sedangkan nilai rata-rata kompetensi pengetahuan IPA siswa untuk kelas kontrol yang dibelajarkan dengan Model Pembelajaran Konvensional adalah 72,41 dengan varians sebesar 88,56 dan standar deviasi 9,41.

Dari data tersebut menunjukkan bahwa kompetensi pengetahuan IPA siswa kelas eksperimen yang dibelajarkan menggunakan Model Pembelajaran Concept Sentence berbantuan Flash Card memiliki nilai rata-rata lebih tinggi daripada kelas kontrol yang dibelajarkan menggunakan pembelajan Konvensional.Berikut tabel deskripsi kompetensi pengetahuan IPA siswa kelas V SD Negeri Gugus Budi Utomo Denpasar Timur tahun ajaran 2017/2018. 
Tabel 1. Deskripsi Penguasaan Komptensi Pengetahuan IPA Kelompok Eksperimen dan Kontrol.

\begin{tabular}{ccc}
\hline Hasil Analisis & Kelompok Eksperimen & Kelompok Kontrol \\
\hline Rata-rata & 81,75 & 72,41 \\
Varians & 105,09 & 88,56 \\
Standar Deviasi & 10,25 & 9,41 \\
\hline
\end{tabular}

Adapun data nilai penguasaan kompetensi pengetahuan IPA kelompok eksperimen dan kelompok kontrol disajikan dalam histogram distribusi frekuensi kompetensi pengetahuan IPA yaitu sebagai berikut.

Tabel 2. Hasil analisis ujit kompetensi pengetahuan IPA

\begin{tabular}{lllllllll}
\hline No & Sampel & $\mathrm{N}$ & $\mathrm{Dk}$ & $\bar{X}$ & $\mathrm{~V}$ & $t_{\text {hitung }}$ & $t_{\text {tabel }}$ & Keterangan \\
\hline 1. & Kelompok & 40 & \multirow{2}{*}{74} & 81,75 & 105,09 & 4,132 & 2,000 & $H_{o}$ ditolak \\
& Eksperimen & 2. & & & \\
2. & Kelompok Kontrol & 36 & & 72,41 & 88,56 & & & \\
\hline
\end{tabular}

Berdasarkan uji hipotesis diperoleh $t_{\text {hitung }}=4,132$ dengan $\mathrm{dk}=40+36-2=74$ dan taraf signifikansi $5 \%$ diperoleh nilai $t_{\text {tabel }}=2,000$ sehingga $t_{\text {hitung }}=4,132>t_{\text {tabel }}=2,000$ maka Ho ditolak dan Ha diterima. Hal ini berarti terdapat pengaruh yang signifikan Model Pembelajaran Concept Sentence berbantuan Flash Card terhadap kompetensi pengetahuan IPA siswa kelas V SD Negeri Gugus Budi Utomo Denpasar Timur tahun ajaran 2017/2018.

Dari perolehan kompetensi pengetahuan pada kedua kelompok dapat diketahui bahwa kedua kelompok yang awalnya memiliki kemampuan yang setara, kemudian setelah diberikan perlakuan pada kelompok eksperimen dengan model pembelajaran Concept Sentence berbantuan Flash Cardsedangkan kelompok kontrol tidak diberikan perlakuan maka perolehan nilai kompetensi pengetahuan IPA mengalami perbedaan. Kompetensi pengetahuan IPA siswa pada kelompok eksperimen lebih baik apabila dibandingkan dengan kompetensi pengetahuan IPA siswa pada kelompok kontrol. Hal ini disebabkan oleh pembelajaran yang diterapkan pada kelompok eksperimen memiliki banyak kelebihan. Pengaruh yang signifikan kompetensi pengetahuan IPA antara kelompok eksperimen dengan kelompok kontrol dikarenakan pada kelompok eksperimen diberikan perlakuan sedangkan kelompok kontrol tidak diberikan perlakuan pada saat pembelajaran. Kelompok eksperimen diberikan perlakuan berupa model pembelajaran Concept Sentence berbantuan Flash Cardmemiliki nilai rata-rata lebih tinggi dibandingkan dengan kelompok kontrol yang menerapkan pembelajaran konvensional.Data yang diperoleh dari penelitian ini kemudian dianalisis menggunakan statistik melalui tahapan yang meliputi yaitu uji normalitas sebaran data, uji homogenitas varians, dan uji hipotesis. Berdasarkan analisis yang dilakukan hasil uji normalitas sebaran data menggunakan rumus Chi-Square menunjukkan kompetensi pengetahuan IPA siswa kelompok eksperimen pada taraf

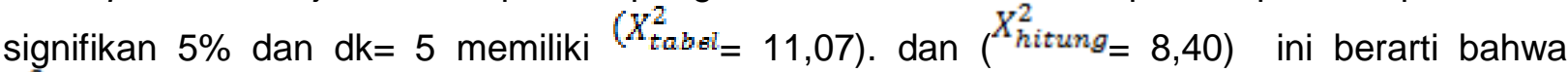

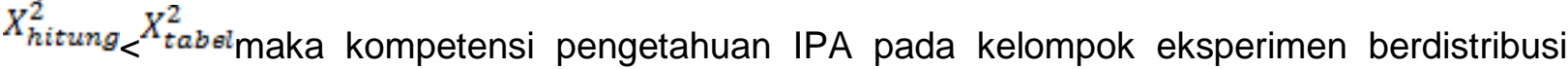
normal. Sedangkan, pada kompetensi pengetahuan IPA siswa dikelompok kontrol pada taraf signifikan $5 \%$ dan $\mathrm{dk}=5$ memiliki $\left({ }^{X_{\text {tabel }}^{2}}=11,07\right)$ dan $\left(X_{\text {hitung }}^{2}=1,98\right)$, ini berarti bahwa $X_{\text {hitung }}^{2} X_{\text {tabel }}^{2}$ maka data kompetensi pengetahuan IPA kelompok kontrol juga berdistribusi normal. Berdasarkan uji normalitas sebaran data terbukti bahwa kompetensi pengetahuan IPA siswa kelompok eksperimen maupun kelompok kontrol berdistribusi normal.

Selanjutnya dilakukan uji homogenitas untuk mengetahui bahwa sebaran data kedua kelompok homogen. Homogenitas varians data kompetensi pengetahuan IPA dianalisis dengan 
uji $F$. Hasil analisis diperoleh $F_{\text {hitung }}=1,19$ dan $F_{\text {tabel }}=1,74$. Hal ini berarti $F_{\text {hitung }}<F_{\text {tabel }}$ sehingga data kedua kelompok memiliki varians yang homogen.

Hipotesis yang diuji dalam penelitian ini adalah Tidak terdapat pengaruh yang signifikan Model Pembelajaran Concept Sentence berbantuan Flash Card terhadap kompetensi pengetahuan IPA siswa kelas V SD Negeri Gugus Budi Utomo Denpasar Timur tahun ajaran 2017/2018. Analisis statistik yang digunakan untuk menguji hipotesis pada penelitian ini yaitu uji $t$ dengan rumus polled varians. Kriteria pengujian yaitu jika $t_{\text {hitung }}>t_{\text {tabel }}$ maka $H_{0}$ ditolak. $t_{\text {tabel }}$ diperoleh dari tabel distribusi t. pada taraf signifikansi $5 \%$ dengan derajat kebebasan (dk) $=n_{1}+n_{2}-2$.

\section{Simpulan dan Saran}

Model pembelajaran Concept Sentence berbantuan media Flash Card dapat diterapkan dalam pembelajaran IPA. Untuk menguji pengaruh model pembelajaran Concept Sentence berbantuan media Flash Card, maka dilakukan suatu penelitian eksperimen. Dalam penelitian ini terdapat dua sampel, satu sampel dijadikan kelompok eksperimen yang dibelajarkan dengan model pembelajaran Concept Sentence berbantuan media Flash Card dan satu sampel lagi dijadikan kelompok kontrol yang dibelajarkan dengan pembelajaran konvensional.

Setelah melakukan penelitian pada siswa kelas V SD Negeri Gugus Budi Utomo Denpasar Timur Tahun Pelajaran 2017/2018 diperoleh hasil yaitu terdapat pengaruh yang signifikan kompetensi pengetahuan IPA antara kelompok siswa yang dibelajarkan melalui model pembelajaran Concept Sentence berbantuan media Flash Card dengan kelompok siswa yang dibelajarkan melalui pembelajaran konvensional. Hasil ini terlihat dari perolehan nilai rata-rata siswa di kelompok eksperimen lebih tinggi dibandingkan dengan nilai rata-rata siswa di kelompok kontrol serta hasil analisis uji hipotesis.

Kompetensi Pengetahuan IPA siswa yang dibelajarkan menggunakan model pembelajaran Concept Sentence berbantuan media Flash Card pada kelompok siswa kelas V SD Negeri Gugus Budi Utomo Denpasar Timur Tahun ajaran 2017/2018 masuk dalam kategori cukup 81,75. Sedangkan Kompotensi Pengetahuan IPA siswa yang dibelajarkan menggunakan pembelajaran konvensional pada kelompok siswa kelas V SD Negeri Gugus Budi Utomo Denpasar Timur Tahun ajaran 2017/2018 masuk dalam kategori cukup dengan nilai rata-rata 72,41 .

Berdasarkan hasil analisis dengan menggunakan uji-t dengan $\mathrm{dk}=74$ pada taraf signifikansi $5 \%$ diperoleh $t_{\text {hitung }}=4,132>t_{\text {tabel }}=2,000$ ini berarti bahwa terdapat pengaruh yang signifikan Model Pembelajaran Concept Sentence berbantuan Flash Card terhadap kompetensi pengetahuan IPA siswa kelas V SD Negeri Gugus Budi Utomo Denpasar Timur tahun ajaran 2017/2018 pada tema 8 lingkungan sahabat kita.

Adapun saran yang dapat disampaikan berdasarkan hasil penelitian yang telah dilakukan yaitu, kepada guru agar lebih kreatif untuk memberikan fasilitas berupa sumber belajar dan kesempatan yang lebih besar bagi siswa pada pembelajaran dengan menggunakan model pembelajaran Concept Sentence berbantuan media Flash Card sehingga tercipta pembelajaran yang menarik bagi siswa. Kepada kepala sekolah agar dapat menggunakan hasil penelitian ini sebagai pendukung sumber belajar guru dalam meningkatkan kualitas pembelajaran dengan menciptakan pembelajaran yang menyenangkan di sekolah sehingga sekolah mampu menghasilkan siswa yang memiliki output berkualitas. Serta kepada peneliti agar hasil penelitian ini digunakan sebagai referensi untuk melaksanakan penelitian selanjutnya atau menemukan inovasi kegiatan pembelajaran lainnya yang bermakna dan menyenangkan bagi siswa. 


\section{Daftar Rujukan}

Agung, A.A. Gede. 2014. Metodelogi Penelitian Pendidikan. Singaraja: Universitas Pendidikan Ganesha.

Anwar, Muhamad. 2015. Filsafat Pendidikan. Jakarta: Prenadamedia Group.

Arsyad, Azhar. 2009. Media Pembelajaran. Jakarta: PT Raja Grafindo Persada.

Fadlillah, M. 2014. Implementasi Kurikulum 2013 Dalam Pembelajaran SD/MI, SMP/Mts \& SMA/MA.

Huda, Miftahul. 2014. Model-Model Pengajaran Dan Pembelajaran. Yogyakarta: Pustaka Pelajar.

Kosasih, E. 2015. Strategi Belajar Dan Pembelajaran. Bandung: Yrama Widya.

Mulyorini. 2014. "Penggunaan Media Flashcard Dalam Model Pembelajaran Langsung UntukMeningkatkan Hasil Belajar Siswa Pada Mata Pelajaran Pkn Kelas V SdnNgagel Rejo I/ 396 Surabaya". E-Jorurnal, FKIP Universitas Negeri Surabaya, Vol 2, Nomor 2.

Prayogo, Dona. 2015. "Pengaruh Penggunaan Kartu Bergambar Terhadap Hasil Belajar IPA Siswa kelas V SD Negeri 3 Labuhan Ratu Kota Bandar Lampung Tahun Ajaran 204/2015". E-Journal, FKIP Universitas Lampung, Vol 3, Nomor 6.

Said, Alamsyah dan Andi Budimanjaya. 2015. 95 Strategi Mengajar Multiple Intelligences. Jakartta: Prenadamedia Group.

Samatowa, Usman. 2016. Pembelajaran IPA di Sekolah Dasar.Jakarta: PT Indeks.

Shoimin, Aris. 2014. 68 Model Pembelajaran Inovatif Dalam Kurikulum 2013. Jakarta: Ar-Ruzz Media.

Sugiyono. 2015. Metode Penelitian Pendidikan. Bandung: Alfabeta.

Sumerti, Ni Luh. 2014. "Pengaruh Model Pembelajaran Kooperatif Tipe Concept Sentence Berbantuan Gambar Berseri Terhadap Keterampilan Menulis Siswa Kelas V SDN 22 Dauh Puri". E-Journal, Mimbar PGSD Universitas Pendidikan Ganesha, Vol 2, Nomor 1.

Susanto, Ahmad. 2015. Teori Belajar \& Pembelajaraan Di Sekolah Dasar. Jakarta: Prenadamedia Group.

Susilana, Rudi dan Cepi Riyana. 2007. Media Pembelajaran. Bandung: Jurusan Kurtekpend FIP UPI.

Wisudawati, Asih dan Eka Sulistyowati . 2015. Metodelogi Pembelajaran IPA. Jakarta: Bumi Aksara. 